\title{
Legal Appraisal of the EU-Russia Relations in Security Matters: a Frozen "Positive Luggage"
}

\section{Introductory notes}

The economic field is not the only area where the European Union (EU) and Russia's relationship tends to develop. In spite of the fact that they develop on a much deeper level in the economic field, the EU and Russia have always paid more attention to international security in global and regional aspects.

After the Ukrainian crisis of 2014 the EU and Russia relations have entered an acute state of crisis. The European parliament in its Resolution of June 10, 2015 on state of EU-Russia relations stressed that the EU cannot envisage a return to 'business as usual' and has no choice but to conduct a critical re-assessment of its relations with Russia. It pointed out that Russia, due to its actions in Crimea and in Eastern Ukraine, can no longer be treated as or considered as a 'strategic partner'.

In March 2016, the EU Foreign Council worked out five principles of new relations with Russia ${ }^{2}$. In this regards, the EU Global Strategy for the Foreign and Security Policy adopted in June 2016, ultimately points out that: "Substantial changes in relations between the EU and Russia are premised upon full respect for international law. At the same time, we will engage Russia to discuss disagreements and cooperate if and when our interests overlap"3.

European Parliament resolution of 10 June 2015 on the state of EU-Russia relations, 2015/2001(INI).

2 The Council agreed on five principles towards Russia: 1. Implementation of the Minsk agreement as the key condition for any substantial change in the EU's stance towards Russia; 2. Strengthened relations with the EU's Eastern Partners and other neighbours, in particular in Central Asia; 3. Strengthening the resilience of the EU (for example energy security, hybrid threats, or strategic communication); 4. Need for selective engagement with Russia on issues of interest to the EU; 5. Need to engage in people-to-people contacts and support Russian civil society. Outcome of the Council Meeting, 3457th Council meeting, Foreign Affairs, Brussels, 14 March 2016. 7042/16, p. 5.

3 "Shared Vision, Common Action: A Stronger Europe". A Global Strategy for the European Union's Foreign and Security Policy. 28.06.2016, p. 33. Available at : https://europa.eu/globalstrategy/en/ shared-vision-common-action-stronger-europe, accessed: 9.09. 2017. 
However, the EU and Russia need each other to answer new challenges (e.g. terrorism, the Islamic State ${ }^{4}$, civil wars in Syria and in Libya, the Iran Nuclear Program and other focal points of Non-Proliferation). In fact, the EU and Russia cannot ignore each other in the global problems agenda. Moreover, Russia and the EU have deeper mutual interdependence in their foreign economic dimension. Ultimately, The EU and Russia have common boarders and common trans-boarder issues. Such problems can be solved jointly and only by common efforts.

The aim of this article is to evaluate the legal basis for the EU-Russia relations in security matters on the background of general deterioration of the partnership between Russia and the EU. This issue, first of all, draws attention to the role of the EU and Russia in global security matters; secondly, it points out to the EU-Russia bilateral agreements in the security field; thirdly, this article is connected with legal aspects of the EU-Russia security relations in the context of soft law and wide dimension of political cooperation.

\section{The role of the EU and Russia in a global security context}

Since the beginning of $21^{\text {st }}$ century the EU has been aspiring to become a global actor. The Laeken Declaration 2001 specially stressed: "What is Europe's role in this changed world? Does Europe not, now that is finally unified, have a leading role to play in a new world order, that of a power able both to play a stabilising role worldwide and to point the way ahead for many countries and peoples?"5. A new key challenge faces the Union and dictates for new amendments in formulating its position as an international actor ${ }^{6}$.

After the Lisbon Treaty 2007 the EU has a modernized competence in this field on the ground of the Treaty on European Union (TEU) and the Treaty on Functioning of the European Union (TFEU) 7 .

Art. 3(5) TEU mentions "security" among the external aims of the EU. International security strengthening on the basis of the UN Charter and Helsinki act and Paris Charter for a New Europe is supposed to be one of the purposes of the EU external policy according to Art. $21 \mathrm{TEU}$. As is well-known, the EU includes two Member States which are Permanent Members of the UN Security Council (France and the UK).

In accordance with provisions of the Title $\mathrm{V}$ of the TEU, the EU conducts the Common Foreign and Security Policy. It coordinates its policy with Euro-Atlantic structures, especially with the North Atlantic Treaty Organization (NATO) in common security and defense policy according to the Art. 42 . The Lisbon Treaty introduced a new position within the framework of the EU Commission: The High Representative of the Union for Foreign Affairs and Security Policy. Furthermore, aiming to strengthen the

4 Prohibited organization within the territory of Russia.

5 The Future of the European Union. Laeken Declaration, Laeken, 15 December 2001, (SN 273/01).

6 Marise Cremona, 'Union as a Global Actor: Roles, Models and Identity' (2004) 41 Common Market Law Review 553-573.

7 Michael Dougan,'The Treaty of Lisbon 2007: Winning Minds, Not Hearts' (2008) 45 Common Market Law Review 617-703. 
Common Foreign and Security Policy, it established the European External Action Service ${ }^{8}$. In June 2016 the EU adopted its Global Strategy for the Foreign and Security Policy, where it particularly stressed that "the EU will be a responsible global stakeholder".

After a period of relative weakness in the end of the last century, Russia is aspiring to have come back as a "great" power in the world politics in a new century ${ }^{10}$. Russia is also a Permanent Member of the UN Security Council. There is no doubt that "ensuring" security is the main priority of the Russias foreign policy in accordance with the Russian Foreign Policy Concept 2016 ${ }^{11}$. Russia keeps being firmly engaged in the world politics and plays the leading role in Eurasian security structures such as the Collective Security Treaty Organisation (CSTO) and the Shanghai Cooperation Organisation (SCO).

Modern relations between the EU and Russia in general and in security matters in particular are considered to be relations of ambivalence. On one hand, the EU, as a "global actor", and Russia, as a "great power", are partners and need each other to respond to new challenges in the dimension of global problems. On the other hand, all we know is that a new brinkmanship between the EU and Russia has to do with the Ukrainian crisis ${ }^{12}$.

\section{Security issues in the EU-Russia bilateral agreements}

\section{EU-Russia Partnership and Cooperation Agreement}

The EU-Russia relations in security matters have always suffered from a lack of hard legal basis. As I mentioned previously, the EU-Russia relationship rests upon three legal layers ${ }^{13}$. The first layer is the EU-Russia Partnership and Cooperation Agreement $(\mathrm{PCA})^{14}$ and other EU-Russia bilateral agreements. The second layer consists of soft law

8 Bart Van Vooren, 'A Legal-Institutional Perspective on the European External Action Service' (2011) 48 Common Market Law Review 475-502.

9 "Shared Vision, Common Action: A Stronger Europe". A Global Strategy for the European Union's Foreign and Security Policy. 28.06.2016, p. 18. Available at : https://europa.eu/globalstrategy/en/ shared-vision-common-action-stronger-europe, accessed: 9.09.2017.

10 See: Jakob Hedenskog, Vilhelm Konnander, Bertil Nygren, Ingmar Oldberg, Christer Pursiainen, Russia as a Great Power: Dimensions of Security Under Putin (Routledge, 2013): Lamont Colucci, 'Great Power Conflict: Will It Return?' (2015) January/February World Affairs. Available at : http:// www.worldaffairsjournal.org/article/great-power-conflict-will-it-return, accessed 9.09.2017.

11 Concept of the Foreign Policy of the Russian Federation approved by President of the Russian Federation on 30 November 2016. Available in the Internet at: http://www.mid.ru/en/foreign_policy/ official_documents/-/asset_publisher/CptICkB6BZ29/content/id/2542248, accessed: 9.09.2017.

12 Paul Kalinichenko, 'Shared values and interests in the conflictual relationship between the EU and Russia, [in:] Sara Poli (ed.), The European Neighbourhood Policy - Values and Principles (Routlege, 2014) 115-129.

13 Paul Kalinichenko, 'Legislative Approximation and Application of EU Law in Russia', [in:] Peter Van Elsuwege \& Roman Petrov (eds.), Legislative Approximation and Application of EU Law in the Eastern Neighbourhood of the European Union: Towards a Common Regulatory Space? (Routlege, 2014) 247.

14 Agreement on partnership and cooperation establishing a partnership between the European Communities and their Member States, of one part, and the Russian Federation, of the other part 1997, OJ L 327, 28.11.1997, p. 1. 
such as 'roadmaps' for the establishment of four EU-Russia Common Spaces. The third layer covers the Russian legislation and the EU acquis within the EU-Russia sectoral cooperation.

The EU-Russia PCA constitutes the core of the EU-Russia relations. This agreement was signed on June 24,1994 in Corfu (Greece) and entered into force on December1, 1997. The EU-Russia PCA has formed a firm foundation for EU-Russia political dialogue and economic, social and cultural cooperation including legislative approximation. It is an 'entry-level' and a 'framework' agreement and a basis for other EU-Russia bilateral agreements ${ }^{15}$.

The EU-Russia basic agreement is mainly dedicated to economic and trade matters. The EU-Russia PCA pursues the objective of establishing a market economy in Russia in preparation of its accession to the WTO. The finalité of the agreement is Russia's integration in the world economy and, in the longer term, the creation of a free trade area between Russia and the EU.

However, isolated provisions in the field of security can be found in the EU-Russia PCA. Firstly, they appear in the Preamble (commitment to promote international peace and security). Secondly, these provisions can be found among the principles of the partnership in the Art. 2 (it links to the Helsinki act and Paris Charter for a New Europe and in this context it responds to the modern TEU provisions). Thirdly, "increasing security" is one of the objectives of the EU-Russia political dialogue in the Art. 6. Finally, Art. 2 of the PCA considers the respect of human rights and other democratic principles established in the Helsinki act 1975 and the Charter of Paris for a New Europe 1990 as an essential element of the partnership. Although these provisions do not take into account the Russian membership in the Council of Europe and the European Convention on Protection of Human Rights and Fundamental Freedoms 1950 as well as the adoption of the EU Charter of Fundamental Rights in 2000, they constitute an important aspect of shared values between Russia and the $\mathrm{EU}^{16}$. Moreover, Russian courts in their practice recognise a direct link between these provisions of the PCA and provisions of the Constitution of Russia $1993^{17}$. Principles and other provisions of the Helsinki act 1975 have always impacted the relations between Russia and the EU and its Member States.

Unfortunately, the PCA does not prioritize security issues in their provisions. Furthermore, as we know the PCA is very old. It was concluded more than 20 years ago. It does not correspond with the current state of mutual relations.

15 Roman Petrov, 'The Partnership and Co-operation Agreements with the Newly Independent States', [in:] Andrea Ott \& Kirstyn Inglis (eds.), Handbook on European Enlargement. A Commentary on the Enlargement Process (The Hague: Asser Asser Press, 2002) 177.

16 Paavi Leino \& Roman Petrov, 'Between 'Common Values' and Competing Universals - The Promotion of the EU's Common Values though the European Neighbourhood Policy' (2009) 515 European Law Journal 669-670.

17 Roman Petrov \& Paul Kalinichenko, 'The Europeanization of Third Country Judiciaries through the Application of the EU Acquis: the Cases of Russia and Ukraine' (2011) 60 International and Comparative Law Quarterly 337-339. 
The described legal framework should be changed. Primarily it concerns the EU-Russia PCA. Russia's WTO accession in 2012 made many of the provisions of the EU-Russia PCA outdated. ${ }^{18}$ Actually, in 2006, Russia initiated negotiations concerning a New Basic Agreement between Russia and the EU to replace the PCA. This initiative was supported by the EU and the negotiations started in 2008. In the period between 2008-2011, the Parties agreed on several key points of the future agreement, but in December 2011, they decided to delay the negotiations. The Ukrainian crisis has finally cut out the New Basic Agreement negotiation process from the EU-Russia agenda.

\section{EU-Russia Agreement on protection of classified information}

It is a well-known fact that in 2010 the EU and Russia concluded the Agreement on the protection of classified information ${ }^{19}$. This agreement is an important step to mutual convergence in the field of external and internal security of the Parties. However, it is a purely technical agreement. It is important to notice that the EU concludes similar agreements with other third countries as well, e.g. with the USA ${ }^{20}$.

This Agreement is applied to the protection of classified information which is provided, exchanged or produced between the Parties in the course of their cooperation. Its provisions should assist and simplify cooperation in security matters according to other agreements or action plans.

The Agreement consists of preamble and 16 articles. The main aim of the Agreement is to approximate procedures for exchanging of classified information during different forms of cooperation between the Parties. In this regard, the Agreement puts into the ground a universal basis for further cooperation between the EU and Russia in the field of security. According to the Agreement, "restricted information" can be divided into "secret" and "top secret". The Agreement provides a legal framework in the field of information security in the context of the EU-Russia common spaces.

\section{Previous experience: participation in the EUPM}

As a matter of fact, previous experience clarified it. The protection of classified information raised between the EU-Russia as a result of the Agreement on Russia's participation in the European Union military operation in the Republic of Chad and in the Central African Republic (Operation EUFOR Tchad/RCA) 2008 ${ }^{21}$, the Agreement on the Russiass participation in the European Union Police Mission (EUPM) in Bosnia

18 Peter Van Elsuwege, 'Towards a Modernisation of EU-Russia Legal Relations?' (2015) 52 CEURUS EU-Russia Papers.

19 Agreement between the Government of the Russian Federation and the European Union on the protection of classified information, (OJ L 155, 22.6.2010, p. 57).

20 Agreement between the European Union and the government of the United States of America on the security of classified information (OJ 2007 L 115, 03.05.2007, p. 30).

21 Agreement between the European Union and the Russian Federation on the participation of the Russian Federation in the European Union military operation in the Republic of Chad and in the Central African Republic (Operation EUFOR Tchad/RCA), (OJ L 307, 18.11.2008, p. 16-20). 
and Herzegovina (BiH) $2003^{22}$ and even the EU Council Joint Action establishing the European Union Cooperation Programme for Non-proliferation and Disarmament in the Russian Federation $1999^{23}$ or the EU Council Joint Action on support of chemical weapons distraction in Russia $2007^{24}$.

In 2002 the United Nations delegated the powers to the European Union to resolve the situation in the former Yugoslavia on the grounds of the Police Mission in Bosnia and Herzegovina ${ }^{25}$. On the basis of a special agreement with Bosnia and Herzegovina, the EU adopted Council Joint Action 2002/210/CFSP of March 112002 on the European Union Police Mission ${ }^{26}$. Those powers were implemented by the EU in the scope of "the second pillar".

The Russian officials have expressed interest in participating in negotiations to join the European Union Police Mission in Bosnia and Herzegovina since its launching in 2003. These steps corresponded with the terms of a UN mandate, with the Agreement between the EU and Bosnia and Herzegovina and finally, with the EU Joint Action. By the middle of 2003 the EU and Russia had achieved an agreement on Russia's participation in the EU Police Mission. After this, the President of Russia signed its Order of July 4, 2003 to send the Russian police officers to the EUPM in Bosnia and Herzegovina ${ }^{27}$. According to the provisions of this agreement, Russia sent five officers of the Russian Internal Affairs Ministry to the EU Police Mission. The Agreement on Russia's participation in the EU Police Mission was concluded for an indefinite period of time. The agreement consists of a preamble, six articles and an exchanging of letters between the Parties.

In spite of its brevity and focus on a narrow practical area of cooperation, the Agreement on Russia's participation in the EU Police Mission 2003 has a historical meaning. This Agreement was the first step in the field of cooperation in the European security matters between Russia and the EU as key players within the European area.

22 Agreement between the European Union and the Russian Federation on the participation of the Russian Federation in the European Union Police Mission (EUPM) in Bosnia and Herzegovina (BiH), (OJ L 197, 5.8.2003, p. 38).

23 1999/878/CFSP: Council Joint Action of 17 December 1999 establishing a European Union Cooperation Programme for Non-proliferation and Disarmament in the Russian Federation, (OJ L 331, 23.12.1999, p. 11-16).

${ }^{24}$ Council Joint Action 2007/178/CFSP of 19 March 2007 in support of chemical weapons destruction in the Russian Federation in the framework of the EU Strategy against Proliferation of Weapons of Mass Destruction, (OJ L 81, 22.3.2007, p. 30-34).

25 Anze Voh Bostic, 'The Role of the European Union's Expert Assistance in the Process of PeaceBuilding: the Case of Bosnia and Herzegovina' (2010) 15 European Foreign Affairs Review 216.

26 Council Joint Action of 11 March 2002 on the European Union Police Mission, (OJ L 70, 13.3.2002, p. 1).

27 Order of the President of the Russian Federation of 4 July 2003 No 336-rp "On the sending the police officers of the Russian Federation in the European Union Police Mission in Bosnia and Herzegovina", (Sobraniye Zakonodatelstva Rossiyskoy Federatsii (the Russian Federation Legislation Collection - SZ RF), No 27, 07.07.2003, art. 2795). 


\section{Previous experience: participation in the EUFOR}

Russia and the EU took serious steps in the field of external security on the basis of the Agreement on the participation of Russia in the European Union military operation in the Republic of Chad and in the Central African Republic (Operation EUFOR Tchad/RCA).

Using the Russian Military Forces outside the territory of the Russian Federation is not just a legal issue. It requires a financial and economic feasibility. Moreover, in accordance with the Art. 102(g) of the Russian Constitution 1993, a decision to use the Military Forces outside the territory of the Russian Federation is approved by the Council of Federation of the Federal Assembly of the Russian Federation.

Russiass participation in the EUFOR Chad/CAR had a serious political and legal basis. It contributed to the measures taken by the UN Security Council to provide peace and security in the World. Afterwards, Russia's participation in the EUFOR Chad/CAR strengthened Russia's position in the foreign policy dialogue with the EU, as well as allowed to work out, in practice, optimal schemes of interaction in the field of crisis management between the EU and Russia.

Resolution of the Security Council of the United Nations 1778 (2007) of September 25, 2007 mandated the European Union to send forces in the Republic of Chad and the Central African Republic. As a result, the Council of the European Union adopted the Joint Action 2007/677/CFSP that indicated the main objectives and instruments of a peacekeeping operation and provided the opportunity for the third countries to participate in the EUFOR Chad/CAR. The Secretary-General of the EU Council/High Representative for the Common Foreign and Security Policy in his letter of December 7, 2007 invited the Russian Federation to consider its participation in the EUFOR Chad/CAR. On April 29, 2008 the EU-Russia Joint Statement on cooperation in crisis management operations expressed the readiness of Russia to such participation.

When it comes to the financial and economic validity of participation in the operation, it should be noted that in accordance with the Agreement Russia allocated a relatively small contingent of peacekeepers - up to 200 personnel and four transport helicopters Mi-8MT (NATO: «Hip») with standard weapons, ammunition, military equipment and other necessary facilities. Accordingly, Russia's participation in the EUFOR Chad/CAR did not require any additional costs from the budget allocated to such needs for the Defense Ministry of Russia.

Taking into consideration these decisions, the Council of Federation of the Federal Assembly of the Russian Federation by its Resolution approved the participation of the Russian military forces in EUFOR Chad/CAR ${ }^{28}$. On the basis of the Resolution of the Council of Federation, the Russian President issued the Decree of September 1, $2008 \mathrm{~N}$

28 Resolution of the Council of Federation of the Russian Federation Federal Assembly on 25 August 2008 N 299-SF "On using of the military units of the Military Forces of the Russian Federation to participate in the European Union operation to support of the UN actions in Chad and the Central African Republic", (SZ RF, No 35, 1.09.2008, art. 3997). 
$1279^{29}$ involving, inter alia, the necessity to sign a special agreement with the European Union. Later on, the EU Council adopted the Decision 2008/868/CFSP on the conclusion of an agreement with Russia ${ }^{30}$.

It is important to stress that these decisions were made by the Parties against the backdrop of the conflict in South Ossetia.

The Agreement on Russia's participation in the EUFOR Chad/CAR was signed on November 5, 2008, and had been applied provisionally from that date in accordance with its Art. 9(2). There is no doubt that the technical revision of Russian authentic text has slightly delayed the process of its ratification in Russia itself. The Agreement on Russia's participation in EUFOR Chad/CAR was ratified by Russia through adoption of the Federal Law of 28.11.2009 № 306-FZ ${ }^{31}$ and entered in force in 2010. The Agreement consists of a preamble, nine articles, Technical Protocol and statements of the Parties.

In accordance with Art. 1 of the Agreement, the Russian military contingent was engaged in the EUFOR on the terms of the UN mandate, the EU Council Joint Action and the Agreements between the EU and Russia. The Russian troops could be withdrawn unilaterally at any time, after the prior consultation between the Parties. Article 4 of the Agreement prescribed for Russian troops to remain under full command of the Russian Party. It should be noted that the military contingent management was totally delegated to the EU in order to contribute to the achievement of the targets of the operation. The status of the Russian military contingent was determined by the Status of Forces Agreement concluded by the European Union and the Republic of Chad, the Central African Republic and the Republic of Cameroon (Art. 2). On top of that, specific technical and administrative conditions for the participation of the Russian military contingent in the EUFOR Chad/CAR were laid down in the Technical Protocol between the Russian Ministry of Defense and the Commander of the EUFOR Chad/CAR.

It is essential to emphasize that both the agreement on Russia's participation in the EU Police Mission and the agreement on Russias participation in the EUFOR were crucial in the context of the protection of classified information issues.

29 Decree of the President of the Russian Federation of 1 September 2008 No 1279 "On sending of the military units of the Military Forces of the Russian Federation to participate in the European Union operation to support of the UN actions in Chad and the Central African Republic", (SZ RF, No 36, 08.09.2008, art. 4088).

${ }^{30}$ Council Decision 2008/868/CFSP of 13 October 2008 concerning the conclusion of the Agreement between the European Union and the Russian Federation on the participation of the Russian Federation in the European Union military operation in the Republic of Chad and in the Central African Republic (Operation EUFOR Tchad/RCA), (OJ L 307, 18.11.2008, p. 15).

31 Federal Law of the Russian Federation of 28.11.2009 № 306-FZ “On the ratification of the Agreement between the European Union and the Russian Federation on the participation of the Russian Federation in the European Union military operation in the Republic of Chad and in the Central African Republic (Operation EUFOR Tchad/RCA)", (SZ RF, No 48, 30.11.2009, art. 5756). 
The main phenomenon that can be observed is that the EU and Russia have a serious positive practical experience in cooperation in the scope of their security policies. However, numerous experts highlighted that the EU and Russia had failed to implement their potential for partnership in the field of security and defense ${ }^{32}$.

\section{Soft law and political cooperation}

\section{The Role of the soft law instruments}

In the best-case scenario, the lack of hard legal basis leads to the increase in the number of soft law instruments. Conclusions and declarations of the EU-Russia summits adopted in early $2000^{\text {th }}$ emphasized the issue of security. It was the period of the Second Chechen War, "9/11" and the fight against Al-Qaeda, when the EU and Russia needed in each other's support in counteracting the international terrorism invasions.

Within this background, two out of four Road Maps on common spaces between the EU and Russia of 2005 are devoted to the security problems ${ }^{33}$. These 'roadmaps' for the establishment of four Common Spaces were adopted at the Russia-EU Summit on May 10, 2005 $5^{34}$ containing a list of practical actions for the future evolution of the EU-Russia relations. However, this list does not establish fixed periods or timetables for the implementation of these actions nor does it envisage any clear instruments of control or responsibility for their implementation. The EU-Russia roadmaps are not legally binding documents but rather acts of a political nature and soft law instruments $^{35}$. Therefore, the EU-Russia roadmaps can be regarded as acts sui generis, the execution of which depends on the political will of the Parties. Accordingly, the roadmaps are not sufficient to create a strong legal basis for the further deepening of EU-Russia relations. In 2010, the EU-Russia roadmaps were supplemented by another soft law initiative - the 'Partnership for Modernisation', which includes a workplan with cooperation activities and common projects ${ }^{36}$.

As for the Road Map on common space of freedom, security and justice, it involves internal security cooperation (migration, terrorism, trans-boarder criminal). Similarly,

32 Tuomas Forsberg, 'The EU-Russia Security Partnership: why the Opportunity was Missed?' (2004) 9 European Foreign Affairs Review 240.

33 Krassimir Nikolov (ed.) Assessing the Common Spaces between the European Union and Russia, (Sofia, 2009).

34 There are roadmaps on a Common Economic Space; a Common Space of Freedom, Security and Justice; a Common Space of External Security; and on a Common Space of Research and Education, including Cultural Aspects. Available at: http://www.eeas.europa.eu/russia/common spaces, accessed: 9.09.2017.

35 See: Peter Van Elsuwege, 'The Four Common Spaces: New Impetus to the EU-Russia Strategic Partnership?', in Marc Maresceau (ed.), Law and Practice of EU External Relations. Salient Features of a Changing Landscape, (Cambridge, Cambridge University Press, 2008) 334-359.

36 See: Joint Statement of the EU-Russia Summit of 31 May 2010 and Working Plan on Partnership for Modernisation of December 2010. For more info see: http://formodernisation.com, accessed: 9.09.2017. 
the Road Map on common space of external security covers external security issues such as terrorism, non-proliferations, crisis management, and civil protection.

\section{The EU-Russia Common Space of External Security}

The Road Map for the EU-Russia Common Space of External Security consists of an introduction and five chapters. The introduction of the Road Map listed objectives and scopes of the measures within the framework of the EU-Russia Common "Third" Space. It should be noted that the purposes of the Road Map come across as totally vague from the legal point of view. There are four sets of objectives to be pointed out:

1. To cooperate with the aim of strengthening of the central role of the United Nations on the basis of the fact that Russia and the European Union share responsibility for the maintenance of "international order based on effective multilateralism";

2. To respond to the current global and regional challenges and key threats by strengthening of co-operation and dialogue on security and crisis management;

3 . To promote the process of regional cooperation and integration in mutually beneficial way through result-oriented cooperation and dialogue between the EU and Russia, thereby making an effective contribution to creating a greater Europe without dividing lines and based on common values.

4. To contribute to the promotion of common values in the international arena.

It is important to note that the Road Map for Common Space of External Security is the only of the four EU-Russia road maps 2005 that directly mentions the PCA as the ground of this Space. The third Roadmap determines that Russia and the EU base their foreign policies on common values "as defined in the Helsinki Final Act and the Agreement on Partnership and Cooperation and other relevant international instruments, in particular, the respect for international law, including respect for democratic principles and human rights, including the rights of persons belonging to minorities, as well as the principle of equality and mutual interests".

The Roadmap for Common Space of External Security lays down five priorities under which the five sections of the document are built:

- Strengthen dialogue and cooperation in the international arena;

- The fight against terrorism;

- Non-proliferation of weapons of mass destruction and their means of delivery, strengthening of export control regimes and disarmament;

- Cooperation in crisis management;

- Cooperation in the field of civil protection.

For each of priority area the Road Map sets forth specific targets and key activities. In addition, the Road Map provides the possibility to develop action plans for specific areas of cooperation between Russia and the EU in the field of external security. The document is full of references to international treaties and other intergovernmental instruments. It underlines the fact that the partnership between the EU and Russia is impossible without coordinating their interests at the global level. 
The Roadmap for Common Space of External Security also provides for a specific monitoring mechanism. Monitoring the implementation of the Third Roadmap puts into the agenda cooperation within existing formats of the meetings within the "troika" of the Political and Security Committee at the level of permanent representatives and consultations of political directors. The Parties are responsible for reporting on the implementation of the Road Map at meetings of the Permanent Partnership Council at the level of ministers and/or ministerial meetings with Russian "troika" of the EU. If necessary, Russia and the European Union adopt conclusions regarding the development of the Third Space.

It is obviously clear that the document is outdated in a number of respects, it does not line up to many of realities of international life of 2010th. Moreover, the Road Map for the Common Space of External Security is placing the outmost importance on the cooperation between Russia and the EU in the framework of the United Nations (UN), the Organization for Security and Cooperation in Europe (OSCE) and the Council of Europe, but saying nothing about the role of NATO in their relationship.

\section{Other instruments}

In 2006 Russia and the EU specified the provisions of the Road Maps for the Northern Dimension policy in the Northern Dimension Political Declaration ${ }^{37}$ and the Northern Dimension Framework Document ${ }^{38}$. However, these documents are rather old and it is necessary to revise them.

It is important to point out that problems of security in energy supply (especially gas supply, so-called "Russian-Ukrainian gas wars") between the EU and Russia led to the conclusion of the Memorandum on early warning between the EU and Russia $2009^{39}$.

As a rule, the EU and Russia in their mutual documents in security matters tend not to mention the NATO as a factor of European security. Besides, this factor is a key issue in practice.

The NATO-Russia relations were suspended due to the Ukrainian crisis. However, Russia and the NATO have a steady basis for the relations. The Founding act of 1997 and the Rome Declaration 2002 opened wider possibilities for any cooperation between them. Russia is a Party of the Partnership for Peace Status of Forces Agreement (PfP SOFA $)^{40}$. This Agreement corresponds to and repeats "word by word" the NATO

37 Political Declaration on the Northern Dimension Policy, available at: http://eeas.europa.eu/north_ dim/docs/nd_political_declaration_2006_en.pdf, accessed: 9.09.2017.

38 Northern Dimension Policy Framework Document, available at: http://eeas.europa.eu/north_dim/ docs/nd_framework_document_2006_en.pdf, accessed: 9.09.2017.

39 Memorandum on an Early Warning Mechanism in the Energy Sector, available at: https://ec.europa. eu/energy/sites/ener/files/documents/2009_11_16_ewm_signed_en.pdf, accessed: 9.09.2017.

40 Federal Law of the Russian Federation of 7.06.2007 No-99-FZ "On the ratification the Agreement among the States Parties to the North Atlantic Treaty and the other States participating in the Partnership for Peace regarding the Status of their Forces on 19 June 1995 and its Additional Protocol", (SZ RF, No 25, 18.06.2007, art. 2976). 
SOFA, the most important NATO legal document after the North Atlantic Treaty. Although, the Parties initiated steps to improve their relationships and renovated the NATO-Russia Council meetings in 2016, it is unlikely to expect that they will restore their relations in the spirit of mutual trust and understanding in the nearest future ${ }^{41}$.

Russia and the EU are still cooperating throughout different universal and regional foras such as UN, OSCE, G20. It allows to bode well for the future.

\section{Conclusions}

The lack of hard legal basis is not the main problem for the EU-Russia relations in security matters. There is a field of unseized opportunities. For instance, Russia refused to participate in the European Neighbourhood Policy and to seriously consider its future NATO membership in 2009 and 2010 in spite of the fact that the US was ready to propose it. The EU rejected to consider the Draft of the Eurosecurity Treaty $y^{42}$ proposed by Russia in 2010. It established the Eastern Partnership without contacts with the Eurasian security structures. While some modifications were proposed, there was very little support for the creation of a new security system in Europe.

However, the EU-Russia Relations in security matters have always suffered from not only the lack of hard legal basis, but also more importantly, from the lack of ground-breaking ideas and concepts. In May 2016, the European Leadership Network submitted to the European External Action Service its survey report on the EU-Russia relations advising to be ready for "a gradual and most likely torturous process of establishing a new regime of co-existence and limited EU-Russia cooperation" ${ }^{\prime 3}$. Likewise, the report of the Valday Club on the future of the EU-Russia relation, which was presented at the same time in Russia, is fully pessimistic and utterly devastating ${ }^{44}$. At the same time, the idea of a Common economic area from Atlantic to Pacific is still on the agenda of Russian external activity in accordance to its Concept of foreign policy $2016^{45}$.

To sum everything up, some relevant directions should be rolled out in order to turn the relation between the EU and Russia in security matters in a positive way:

41 Jonathan Marcus, NATO and Russia - in search of dialogue, BBC News, 13 June 2016, available at: http://www.bbc.com/news/world-europe-36779429, accessed: 9.09.2017.

42 The draft of the European Security Treaty, available at: http://en.kremlin.ru/events/president/ news/6152, accessed: 9.09.2017.

43 What is the future for EU-Russia relations? A survey of European Leadership Network members for the EU's Global Strategy on foreign and security policy. May 2016. Available at: https://europa.eu/ globalstrategy/en/what-future-eu-russia-relations-survey-european-leadership-network-memberseus-global-strategy, accessed: 9.09.2017.

44 Russia and the European Union: Three Questions Concerning New Principles in Bilateral Relations. Valdai Discussion Club Report. Moscow, 2016. Available at: http://valdaiclub.com/files/10754, accessed: 9.09.2017.

45 See Concept of the Foreign Policy of the Russian Federation approved by President of the Russian Federation on 30 November 2016, paras 63. Available in the Internet at: http://www.mid.ru/en/ foreign_policy/official_documents/-/asset_publisher/CptICkB6BZ29/content/id/2542248, accessed: 9.09.2017. 
Pobrane z czasopisma Wschód Europy http://journals.umcs.pl/we

Data: 26/04/2023 14:49:01

Legal Appraisal of the EU-Russia Relations in Security Matters: a Frozen "Positive Luggage"

- To stop the political game around Ukraine;

- To renovate the OSCE and its role in ensuring the European security;

- To start working out a New Political and Legal Document for European Security in $21^{\text {st }}$ century;

- To make new international platforms for security cooperation in Eurasia, e.g. between the EU and the Shanghai Cooperation Organisation or between the EU and the CSTO;

- To reload the NATO-Russia relations.

The EU and Russia are condemned to integration in the economic field. The Ukrainian crisis has showed us that it is not enough for ensuring peace and security in Europe. We need to restore peace and good neighborliness as well as strive for a new scheme of peace and security in Europe.

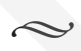

\begin{abstract}
The aim of this article is to evaluate the legal basis for the EU-Russia relations in security matters on the background of general deterioration of the partnership between Russia and the EU. This issue, first of all, focuses on the role of the EU and Russia in global security matters; secondly, it points out to the EU-Russia bilateral agreements in the security field; thirdly, this article is connected with the legal aspects of the EU-Russia security relations in the context of soft law and wide dimension of political cooperation.
\end{abstract}

Keywords: European Union (EU), Russia, international security, European law, International law, PCA, EUPM, EUFOR

\title{
Ocena prawna stosunków UE-Rosja w kwestii bezpieczeństwa: zamrożony „pozytywny bagaż"
}

Streszczenie: Celem artykułu jest ocena podstawy prawnej stosunków UE-Rosja w sprawach bezpieczeństwa na tle ogólnego pogorszenia partnerstwa między Rosją a UE. Temat ten po pierwsze przede wszystkim podkreśla rolę UE i Rosji w kwestiach globalnego bezpieczeństwa; po drugie, wskazuje na dwustronne porozumienia UE-Rosja w dziedzinie bezpieczeństwa; po trzecie, artykuł łączy się z prawnymi aspektami stosunków bezpieczeństwa między UE a Rosją w kontekście miękkiego prawa i szerokiego wymiaru współpracy politycznej.

Słowa kluczowe: Unia Europejska (UE), Rosja, bezpieczeństwo międzynarodowe, prawo europejskie, prawo międzynarodowe, PCA, EUPM, EUFOR

\section{Юридическая оценка отношений между ЕС и Россией в вопросах безопасности: замороженный «позитивный багаж»}

Аннотация: Целью настоящей статьи является оценка правовой основы отношений между ЕС и Россией в вопросах безопасности на фоне общего ухудшения партнерских отношений между 
Россией и ЕС. Этот вопрос, в первую очередь, обращает внимание на роль ЕС и России в вопросах глобальной безопасности; во-вторых, он указывает на двусторонние соглашения между EC и Россией в сфере безопасности; в-третьих, эта статья связана с правовыми аспектами отношений безопасности между ЕС и Россией в контексте мягкого права и широкого измерения политического сотрудничества.

Ключевые слова: Европейский Союз (ЕС), Россия, международная безопасность, европейское право, международное право

\section{Bibliography}

Lamont Colucci, 'Great Power Conflict: Will It Return?' (2015) January/February World Affairs. Available at: http://www.worldaffairsjournal.org/article/great-power-conflict-will-it-return, accessed: 9.02.2017.

Marise Cremona, 'Union as a Global Actor: Roles, Models and Identity' (2004) 41 Common Market Law Review 553-573.

Michael Dougan,'The Treaty of Lisbon 2007: Winning Minds, Not Hearts' (2008) 45 Common Market Law Review 617-703.

Tuomas Forsberg, 'The EU-Russia Security Partnership: why the Opportunity was Missed?' (2004) 9 European Foreign Affairs Review 240.

Jakob Hedenskog, Vilhelm Konnander, Bertil Nygren, Ingmar Oldberg, Christer Pursiainen, Russia as a Great Power: Dimensions of Security Under Putin (Routledge, 2013).

Paul Kalinichenko, 'Shared values and interests in the conflictual relationship between the EU and Russia', in: Sara Poli (ed.), The European Neighbourhood Policy - Values and Principles (Routlege, 2014) 115-129.

Paul Kalinichenko, 'Legislative Approximation and Application of EU Law in Russia', in Peter Van Elsuwege \& Roman Petrov (eds.), Legislative Approximation and Application of EU Law in the Eastern Neighbourhood of the European Union: Towards a Common Regulatory Space? (Routlege, 2014) 247.

Paavi Leino \& Roman Petrov, 'Between 'Common Values' and Competing Universals - The Promotion of the EU's Common Values though the European Neighbourhood Policy' (2009) 515 European Law Journal 669-670.

Krassimir Nikolov (ed.) Assessing the Common Spaces between the European Union and Russia, (Sofia, 2009).

Roman Petrov, 'The Partnership and Co-operation Agreements with the Newly Independent States', in Andrea Ott \& Kirstyn Inglis (eds.), Handbook on European Enlargement. A Commentary on the Enlargement Process (The Hague: Asser Asser Press, 2002) 177.

Roman Petrov \& Paul Kalinichenko, 'The Europeanization of Third Country Judiciaries through the Application of the EU Acquis: the Cases of Russia and Ukraine' (2011) 60 International and Comparative Law Quarterly 337-339.

Peter Van Elsuwege, 'Towards a Modernisation of EU-Russia Legal Relations?' (2015) 52 CEURUS EU-Russia Papers. 
Pobrane z czasopisma Wschód Europy http://journals.umcs.pl/we

Data: 26/04/2023 14:49:01

Peter Van Elsuwege, 'The Four Common Spaces: New Impetus to the EU-Russia Strategic Partnership?', in Marc Maresceau (ed.), Law and Practice of EU External Relations. Salient Features of a Changing Landscape, (Cambridge, Cambridge University Press, 2008) 334-359.

Bart Van Vooren, 'A Legal-Institutional Perspective on the European External Action Service' (2011) 48 Common Market Law Review 475-502.

Anze Voh Bostic, 'The Role of the European Union's Expert Assistance in the Process of Peace-Building: the Case of Bosnia and Herzegovina' (2010) 15 European Foreign Affairs Review 216. 